Please do not remove this page

RMIT

UNIVERSITY

\title{
Dioxin-like compounds in Australian sewage sludge - Review and national survey
}

Clarke, Bradley; Porter, Nichola; Symons, Robert; Blackbeard, Judy; Ades, Peter; Marriott, Philip https://researchrepository.rmit.edu.au/esploro/outputs/9921858903701341/filesAndLinks?institution=61 RMIT_INST\&index=null

Clarke, B., Porter, N., Symons, R., Blackbeard, J., Ades, P., \& Marriott, P. (2008). Dioxin-like compounds in Australian sewage sludge - Review and national survey. Chemosphere, 72(8), 1215-1228.

https://doi.org/10.1016/j.chemosphere.2008.01.076

Published Version: https://doi.org/10.1016/j.chemosphere.2008.01.076

Repository homepage: https://researchrepository.rmit.edu.au

Copyright (c) 2008 Elsevier Ltd All rights reserved.

Downloaded On 2023/04/27 01:15:48 +1000 

no. 8 , pp. 1215-1228.

\section{Literature Review and National Survey}

4 Bradley Clarke1,2*, Robert Symons3, Philip Marriott1, Judy Blackbeard2, Peter

$5 \quad$ Ades4, Nichola Porter1,2

7 1School of Applied Sciences, RMIT University, Melbourne, Victoria, Australia

8 2Co-operative Research Centre for Water Quality and Treatment - Wastewater

9 Program, Melbourne, Victoria, Australia

10 3National Measurement Institute, Sydney, NSW, Australia

11 4School of Forest and Ecosystem Science, University of Melbourne, Parkville,

12 Victoria, Australia

$13 *$ Corresponding Author

14 RMIT University

15 School of Applied Science (Bld 3 Level 1)

$16 \quad$ Fax +6199925 3747

$17 \quad$ Phone +61999252117

18 bradley.clarke@student.rmit.edu.au

20 Keywords

21 Sewage sludge; dioxins, furans; persistent organic pollutants; biosolids 
24 An Australian survey of dioxin-like compounds in sewage sludge was conducted in two parts (a) a national survey, and (b) a time-study. All sewage sludge samples analysed as part of these studies had low overall concentrations of dioxin-like compounds. Out of thirty-seven samples, all except one, were within the reported concentration range of soil within the Australian environment; $0.05-23 \mathrm{WHO}_{98}$ TEQ $\mathrm{ng} \mathrm{kg}^{-1}$ (Muller et al., 2004). The mean concentration of dioxin-like compounds in the Australian sewage sludge survey of 2006 was found to be 5.6 (s.d. 4.5) $\mathrm{WHO}_{05}$ TEQ $n g \mathrm{~kg}^{-1}(\mathrm{n}=14)$ and were within the range of 1.2 to $15.3 \mathrm{WHO}_{05}$ TEQ $\mathrm{ng} \mathrm{kg}^{-1}$. All the Australian sewage sludge samples cited in these studies were below the Victorian EPA “investigation limit” of $50 \mathrm{WHO}_{98}$ TEQ $\mathrm{ng} \mathrm{kg}^{-1}$, well below the European proposed guidelines of $100 \mathrm{WHO}_{98}$ TEQ $\mathrm{ng} \mathrm{kg}^{-1}$, and also below the most stringent guidelines internationally i.e. Canada's 27 I-TEQ ng kg ${ }^{-1}$. The burden of dioxin-like compounds in Australian sewage sludge is low and its land application as biosolids is not likely to pose a problem.

A general positive relationship was found between population of the town producing the waste and both dioxin-like PCDD/Fs and dioxin-like PCBs. The one exception to this trend was sludge from a town that had a history of smelting that had a relatively high burden of dioxin-like compounds. Sludge from a rural WWTP also had a higher burden of dioxin-like compounds. The treatment plant services a geographically isolated town with a low population and no known emitters of dioxin-like compounds. However, this sample also had a relatively high burden of dioxin-like PCBs, which could be the source of the dioxin-like PCDD/Fs found in this sludge. The time study showed analyzing sludges from three WWTP from the same city between the years 2002 and 2006 found no apparent difference between WWTPs but a statistically 
48 significant decline of $1.49 \mathrm{WHO}_{05}$ TEQ $\mathrm{ng} \mathrm{kg}^{-1}$ per year. Also, a comprehensive

49 review of the scientific literature, presents typical levels and sources of dioxin-like 50 compounds in international sewage sludges.

51 


\section{Introduction}

53 Sewage sludge is a useful fertilizer and has many components that can contribute

54 positively to soil health but it can be contaminated with organic pollutants making it

55 unsuitable for land application. One such class of organic pollutants, often referred to

56 as 'dioxin-like compounds', includes the twenty-nine most toxic dioxin-like

57 congeners as defined by the World Health Organization (WHO); seven

58 polychlorinated dibenzo- $\rho$-dioxins (PCDDs), ten polychlorinated dibenzofurans

59 (PCDFs) and the twelve co-planar "dioxin-like" polychlorinated biphenyls (PCBs)

60 (Van den Berg et al., 2006). Here we present a review of the scientific literature

61 related to dioxin-like compounds in sewage sludge followed by the results of an

62 investigation into dioxin-like compounds within Australian sewage sludge. This

63 investigation was completed in two parts: (1) an Australian survey of dioxin-like

64 compounds in sewage sludge completed in 2006 and (2) an analysis of the

65 concentration of dioxin-like compounds in sewage sludge from three wastewater

66 treatment plants (WWTPs) between the years 2002 and 2006.

67 The concentration of dioxin-like compounds is reported using Toxicity Equivalency

68 (TEQ) which assigns Toxicity Equivalency Factors (TEFs) to each congener relative

69 to the most toxic congener 2,3,7,8-TCDD (assigned a value of 1), and summing the

70 products to gain a single comparable value. There have been a number of systems,

71 including the International TEQ (I-TEQ) which was largely developed by the United

72 States Environmental Protection Agency (U.S. EPA) (Kutz et al., 1990). The World

73 Health Organization modified that system in 1998 (WHO W $_{98}$ TEQ) by incorporating

74 "dioxin-like" PCBs and this system was updated in 2005 and published in 2006

75 (WHO (WE TEQ) (Van den Berg et al., 1998; Van den Berg et al., 2006). Changes to the

76 TEQ scheme by WHO are relatively few but can make a significant difference to the 
overall TEQ, particularly with soils and sludges. This is most evident for sewage sludge samples which are high in OCDD, a compound whose TEF was reduced by a factor of ten in formulating $\mathrm{WHO}_{98}$ TEQ factors.

While much work has been done on dioxin-like compounds in the Australian environment (DEH, 2005), little work has been completed on dioxin-like concentrations in sludge. Consequently there is little in the form of guidelines for regulating acceptable concentration of dioxin-like compounds in sludge for land application from either the State or Commonwealth regulatory authorities (NRMMC, 2004). In 2004, the Victorian Environment Protection Authority (EPA Victoria) proposed an "investigation limit" of $50 \mathrm{WHO}_{98}$ TEQ ng kg ${ }^{-1} \mathrm{~d}$.w. in their "Biosolids Land Application" guidelines but does not require that testing be conducted automatically (EPA Victoria, 2004). To date there are no other regulatory agencies within Australia that require monitoring of dioxin-like compounds in sludge. Internationally there are varying guidelines for the safe use of sludge. The U.S. EPA had proposed amending management standards by adding a numeric concentration limit of 300 I-TEQ ng kg-1 for dioxin-like compounds in land-applied sewage sludge (Alvarado et al., 2001). However, in 2003, the U.S. EPA stated that "numerical limitations nor requirements for management practices are currently needed to protect human health and the environment from reasonably anticipated adverse effects from dioxin-like compounds and dioxin-like compounds in land applied sewage sludge" (U.S. EPA, 2003). In Canada, levels have been set for dioxin-like compounds in sludge applied to agricultural land on both a restricted and unrestricted basis of $100 \mathrm{I}-$ TEQ ng kg-1 and 27 I-TEQ ng kg ${ }^{-1}$, respectively. The European Union initially recommended a limit of 100 I-TEQ $\mathrm{ng} \mathrm{kg}^{-1}$ for member countries in the third draft of the Working document on sludge which was later recanted (European Union, 2001). 
102 However Germany and Austria did set a maximum limit of 100 I-TEQ ng kg${ }^{-1}$ in

103 conjunction with maximum sludge application rates (European Commission, 2001).

104 Regardless of whether or not sewage sludge is used as a fertilizer, it is important to

105 monitor sewage sludge for chemical pollutants as the purpose of wastewater treatment

106 is to contain and prevent pollutants from being re-released into the environment. In

107 addition, sewage sludge is an important sink that can lead to the concentration of

108 these Persistent Organic Pollutants (POPs). As Jensen noted "If sludge had been

109 analysed earlier, PCB might have been discovered [accumulating in the environment]

110 as the result of a systematic search instead of by accident” (Jensen, 1972).

\section{$111 \quad 2.1$ Historical Levels of Dioxin-like Compounds in Sewage Sludge}

112 Research investigating dioxin-like compounds in sewage sludge has been completed

113 in the U.S.A, Germany, Sweden, England, Spain, Switzerland and more recently,

114 China. In Australia, almost no research has been carried out on the levels of dioxin-

115 like compounds in sewage sludge. Research into dioxin-like compounds is

116 continually evolving with respect to trends, methods and knowledge that can cause

117 difficulties when comparing results. An unfortunate trend has been the omission of

118 raw data (such as isomer and homologue concentrations) due to the summarizing of

119 data to the standards of the day, but these have changed over the last thirty years. The

120 evolution of the three main TEQ systems can make the updating of old literature and

121 its comparison with modern data difficult, particularly if authors only presented TEQ

122 values.

123 The most basic assumptions about dioxin-like compounds in the environment are that

124 they are anthropogenically produced and released into the environment (IPCS, 1989).

125 Also during the WWTP process, dioxin-like compounds partition almost exclusively 
126 into sewage sludge organic fraction as they are highly lipophilic i.e. $\mathrm{K}_{\mathrm{OW}} \mathrm{S}$ of 4.26 to

127 12.26 (IPCS, 1989). All results presented in the following discussion are on a dry

128 weight (d.w.) basis unless otherwise stated.

$129 \mathrm{PCDD} /$ Fs levels in sewage sludge were first reported in 1984 by Lamparski et al. who 130 analysed two contemporary $(1981,1982)$ and one archived sample (1933). Somewhat 131 surprisingly, Lamparski et al. reported similar levels of PCDD/PCDFs in the modern 132 and archived samples, all containing $60000 \mathrm{ng} \mathrm{kg}^{-1}$ OCDD (Lamparski et al., 133 1984). There was an increase in the concentration of 2,3,7,8-TCDD from 2.2 in 1933 134 to $16 \mathrm{ng} \mathrm{kg}^{-1}$ in 1982. In 1985 Weerasinghe et al. reported PCDD/F levels in two

135 New York State sewage sludge samples: one urban and one rural. They found that the 136 urban sludge contained approximately seven times more HxCDD, HpCDD and 137 OCDD than the rural sludge. The OCDD concentrations were 60000 urban and 7 138600 OCDD ng kg-1 d.w. in the rural sludge.

139 Hagenmaier et al. (1986) were the first to publish the results of contaminated sludges, 140 which be unsuitable for land application, reporting concentrations of 60 to $370 \mathrm{ng} \mathrm{kg}^{-1}$ $1412,3,7,8-\mathrm{TCDD}$ and up to $200,000 \mathrm{ng} \mathrm{kg}{ }^{-1}$ OCDD. In 1989, Rappe et al. monitored the 142 concentration of PCDD/Fs through a WWTP in a highly industrialized area and a 143 WWTP in a rural area, finding similar levels and congener profiles in both (Rappe et 144 al., 1989). In 1988 and 1989, the U.S. EPA conducted the "National Sewage Sludge 145 Survey" of 181 publicly owned treatment works (POTWs) in the United States of 146 America (USA). While the raw data are available, no report with a discussion of 147 results was completed by the U.S. EPA. However, in 1990 Telliard et al. reported 148 selected data from this survey. The data were presented on a wet weight basis without 149 TEQ values, resulting in their data being unsuitable for comparison with other work 150 (Telliard et al., 1990). Nevertheless, they found a positive association between 
$151 \mathrm{PCDD} / \mathrm{F}$ levels and organic matter (or suspended solids), which supports the theory

152 that dioxin-like compounds will partition almost exclusively onto the organic matter

153 in sludge in preference to water.

154 In 1994 Rappe et al. continued work into PCDD/F levels in sewage sludge. They

155 reported the results of 30 sewage sludge samples from Switzerland finding that the

156 concentration ranged from 6 to 4100 I-TEQ $\mathrm{ng} \mathrm{kg}^{-1}$ (Rappe et al., 1994). Rappe et al.

157 reported the most serious incidences of sewage sludge contamination to that point in

158 time of $1100,1900,4100$ and 1700 I-TEQ $\mathrm{ng} \mathrm{kg}^{-1}$. Rappe et al. followed up this work

159 in 1997 and analyzed samples from the same WWTPs finding that in "eight out of ten

160 samples the PCDD/Fs concentration shows a more or less pronounced decrease"

161 (Rappe et al., 1997).

162 Sewart et al. (1995) reported the concentration of 12 digested U.K. sludges finding

163 'minimal' contamination; 1 - 3.8 2,3,7,8-TCDD ng kg-1, 650 - 63000 OCDD ng kg-1

164 and 19 - 206 I-TEQ $\mathrm{ng} \mathrm{kg}^{-1}$. The work went further analyzing archived samples from

165 the years 1940 to 1960 . The results show an increase in PCDD/Fs in sludge from

1661942 (OCDD $1000 \mathrm{ng} \mathrm{kg}^{-1}$ ) peaking in the mid-1950s (OCDD $170000 \mathrm{ng} \mathrm{kg}^{-1}$ ) before

167 beginning to decrease to the average 1992 concentration of 12000 OCDD ng kg-1 .

168 This is a good example of the effect that the change in TEF weighting can have on

169 reported and perceived PCDD/F burden i.e. 170000 OCDD $\mathrm{ng} \mathrm{kg}^{-1}$ is equivalent to

170170 I-TEQ $\mathrm{ng} \mathrm{kg}^{-1}$ and $17 \mathrm{WHO}_{98}$ TEQ $\mathrm{ng} \mathrm{kg}{ }^{-1}$.

171 Following on from their earlier work and the U.S. EPA's earlier national survey,

172 Rappe et al. (1998) reported that the levels of dioxin-like compounds in U.S.A. and

173 Swedish sludge samples had, in general, decreased by $35-50 \%$ except at sites that had

174 "historical contamination" (Rappe et al., 1998). This finding was supported by the

175 work of Alvarado et al. (2001) who reported that dioxin-like compounds in U.S.A. 
176 sludges had decreased from an average of 60.5 to $41.1 \mathrm{WHO}_{98}$ TEQ $\mathrm{ng} \mathrm{kg}^{-1}$ between

177 the years 1994 2001, or approximately 32\% (Alvarado et al., 2001).

178 In 1998, Rappe et al. found serious contamination in two sludges from the U.S.A.; I-

179 TEQ of 1270 and $1240 \mathrm{ng} \mathrm{kg}^{-1}$. The concentration of 480,000 OCDD $\mathrm{ng} \mathrm{kg}^{-1}$ as

180 reported by Rappe et al. translates to 480 I-TEQ $\mathrm{ng} \mathrm{kg}{ }^{-1}$ and $48 \mathrm{WHO}_{98}$ TEQ $\mathrm{ng} \mathrm{kg}^{-1}$.

181 The latest work to be published on the levels of dioxin-like compounds in sludge is by

182 Dai et al. from China. The concentration of dioxin-like compounds reported were

183 low; 2,3,7,8-TCDD <d.1. (n=5) - 7.61 ng kg-1 $34.90-828.78$ OCDD ng kg${ }^{-1}, 3.47-$

184 88.24 I-TEQ ng kg${ }^{-1}$ (Dai et al., 2007). A summary of literature data is presented in

185 Table 1, including 2,3,7,8-TCDD, OCDD and TEQ concentrations.

186 In summary, the concentration of dioxin-like compounds has generally declined since

187 measurements and monitoring programs began (1984). There have been incidents of

188 seriously contaminated sludges reported in Germany and U.S.A. with OCDD

189 concentrations exceeding 200,000 $\mathrm{ng} \mathrm{kg}^{-1}$ and correspondingly high TEQ values.

190 However, these high levels of contamination are not common and have been

191 associated with a known source. There appears to be a difference in the burden of

192 dioxin-like compounds between rural ( 1,000-10,000 OCDD ng kg-1) and urban

$193\left(60,000\right.$ OCDD ng kg$\left.{ }^{-1}\right)$ sources.

\subsection{Sources of Dioxin-Like compounds in Sewage Sludge}

195 The main sources of dioxin-like compounds can be grouped under the headings

196 industrial effluents; surface run-off (including atmospheric deposition); household

197 wastewater; and formation within treatment works. The most common assumption is

198 that dioxin-like compounds are produced as by-products of chlorinated chemical

199 production and combustion processes. However, the sources of dioxin-like 
compounds in the various sludges examined are not completely understood, although

201 a wide range of sources have been identified which can explain the bulk of dioxin-like compounds found in sewage sludge. An effective strategy for identifying potential sources of dioxin-like compounds in both sewage sludge and the environment is

204 through congener profiling which compares the ratio of individual PCDD/F congeners 205 in environmental samples with known sources.

206 Lamparski et al. (1984) found that two contemporary sludges $(1981,1982)$ and an 207 archived sludge (1933) contained similar concentration of OCDD (60,000 ng kg$\left.{ }^{-1}\right)$. 208 This result is surprising given that the industrial production of chlorinated chemicals 209 such as PCP and PCBs was still in its infancy in the 1930s; therefore the dioxin-like 210 compounds in the 1933 samples must have had another source. Not only is this the 211 first paper in this area, but it contradicts the established theory of contamination 212 which argues that dioxin-like compounds largely arise as by-products of chlorinated 213 chemical production. Lamparski et al. hypothesized that PCDD/Fs may be formed in214 situ as by-products of chlorination of wastewater (Lamparski et al., 1984). This 215 suggestion of in-situ formation of PCDD/Fs has not received much follow up in terms 216 of further experimental work by other researchers. Rivera et al. (1997) investigated $217 \mathrm{PCDD} / \mathrm{F}$ formation resulting from the chlorination of potable water in a real and pilot 218 water treatment plant, with and without pre-chlorination respectively. They found 219 that "the results obtained did not reveal a marked influence of chlorination in the 220 formation of PCDFs/PCDDs". Interestingly, the concentration of higher chlorinated 221 PCDDs (HpCDD and OCDD) was higher in the pilot WWTP where the treatment 222 process did not include pre-chlorination (Rivera et al., 1997).

223 In 1985, Weerasinghe et al. (1985) found that an urban sludge contained about seven 224 times more HxCDD, HpCDD and OCDD than rural sludge (60 $000 \mathrm{OCDD}_{\mathrm{ng} \mathrm{kg}}{ }^{-1}$; 
225 urban, $7600 \mathrm{OCDD} \mathrm{ng} \mathrm{kg}^{-1}$ rural). Weerasinghe et al. (1985) associated these

226 increased PCDD/F levels with pentachlorophenol (PCP) use in wood

227 treatment/preservation in the urban area. This conclusion was supported by research

228 that compared the PCDD/F congener and homologue patterns of 43 German sludges

229 with those of stack emissions from waste incinerators and pentachlorophenol (PCP)

230 use, finding that the main sources of PCDD/F contamination in the sludges they

231 examined were from industrial use of PCP and sodium-pentachlorophenate

232 (Hagenmaier et al., 1986).

233 Tiernan et al. (1997) also found that the urban sludges contained significantly higher

234 concentrations of dioxin-like compounds than rural samples $(70-98 \%$ less, $n=31)$.

235 Supporting this, Rappe et al. (1994) published the results of thirty sludge samples

236 finding that "in general the concentrations were found to be higher in the urban areas"

237 and that "the highest inputs could be correlated to local industrial sources". Attention

238 was focused on the PCDD/F levels of relatively "uncontaminated" sludges. Based on

239 limited evidence, it was asserted that the PCDD/Fs "found in background samples of

240 sewage sludge are best explained by direct contamination by pentachlorophenol and

241 by secondary biological reactions in the sewer system" i.e. the formation of dioxin-

242 like compounds from chlorinated benzenes such as PCP (Rappe et al., 1994). Rappe

243 et al. do not discuss the hypothesis originally proposed by Lamparski et al. (1984),

244 that dioxin-like compounds are formed in-situ as a result of chlorination or some other

245 mechanism. The "de novo" formation of dioxin-like compounds in-vitro was reported

246 by Oberg et al. (1992) finding the biochemical transformation of eight different

247 chlorophenyls into OCDD (Oberg and Rappe, 1992). While it was recognized early

248 in this field that PCP use in both wood preservation and textiles was a significant 
249 source of contamination, this work identified PCP not only as a primary source of

250 contamination, but also as a secondary source (Oberg and Rappe, 1992).

251 Since humans are constantly exposed to dioxin-like compounds through their diet, it 252 is possible that they excrete small amounts of dioxin-like compounds through faeces. 253 However, two studies (Wendling et al., 1990; Rappe and Andersson, 1992) found that 254 the levels of dioxin-like compounds in human faeces are extremely low (i.e.

255 approximately 3.9 I-TEQ $\mathrm{ng} \mathrm{kg}^{-1}$ ) and therefore not likely to constitute a major input 256 source of dioxin-like compounds in sludge. However, the congener profile of human 257 faeces was similar to that of "uncontaminated" sludge, with the main congener 258 present being OCDD and almost all the 2,3,7,8- substituted congeners being present 259 (Rappe and Andersson, 1992). Rappe et al. reported a good correlation between the 260 individual congeners found in these samples and in other samples, such as human fat. 261 Rappe et al. argued that the known sources of dioxin-like compounds excreted by the 262 human body cannot alone account for the levels of dioxin-like compounds found in 263 sludge (Rappe and Andersson, 1992).

264 In 1992, Horstmann et al. published the first of a series of studies that attempted to 265 identify the source of dioxin-like compounds in sewage sludge. The first experiment 266 involved measuring urban particulates including street runoff and atmospheric 267 deposition. They found that while urban runoff may contribute to dioxin-like 268 compounds in sludge, it could not explain the bulk of dioxin-like compounds. In 269 1993, Horstmann et al. reported that household wastewater had been underestimated 270 as a dioxin-like compound source relative to urban surface water run-off. They 271 reported that the congener pattern in laundry wastewater was virtually identical to the 272 pattern observed in sewage sludge (Horstmann et al., 1993). They also attempted to 273 estimate the contribution of surface runoff to the PCDD/F flux. They measured 
$274 \mathrm{PCDD} / \mathrm{F}$ concentrations in primary sludge during periods of dry weather and directly 275 after rain events, but found no significant difference. They went further and provided 276 evidence that household waste-water contributed the majority (two to seven times) of 277 the dioxin-like compounds found in sewage sludge compared to other sources. They 278 concluded that grey water from the washing of contaminated clothing (i.e. PCP use in textiles) and subsequently human skin accounted for the majority of dioxin-like compounds found in German sludges (Horstmann and McLachlan, 1995). It is worth noting that countries such as Australia have separate systems to deal with storm-water and sewage, therefore contaminated storm water in Australia, and other country with

283 separate stormwater systems, is a less likely contributor of dioxin-like compounds in 284 sludge.

285 Research published in 1997 by Rivera et al. showed PCDD/F levels in sludge 286 produced from a potable water treatment plant to be similar to those of sewage sludge (2,3,7,8-TCDD $3.7 \mathrm{ng} \mathrm{kg}^{-1}$, OCDD $2447.0 \mathrm{ng} \mathrm{kg}{ }^{-1}$ ) (Rivera et al., 1997). The

288 congener profiles of the membrane sludges corresponds well with sewage sludges and 289 suggest a "common source of origin" (Rivera et al., 1997).

290 Studies have found that certain dioxin-like compounds can be formed through the 291 WWTP process. Klimm et al. found a two-fold increase of OCDD and HpCDD from 292 semi-anaerobic digestion over 192 days (Klimm et al., 1998). They also reported that 293 no other PCDD/Fs were formed and that the formation of HpCDD and OCDD did not 294 occur under strictly aerobic or anaerobic conditions.

295 In 2001, Stevens reported (UK sewage sludges) that "the homologue group pattern of 296 the PCDD/Fs is dominated by the HpCDD and OCDD and is consistent with that 297 found in most sewage sludges" and that "there appears to be no correlation between 298 the degree of industrial input and the PCDD/F concentration (Stevens et al., 2001). 
299 To summarize the conclusions of the above studies it appears that PCDD/F levels in

300 'highly contaminated' sewage sludge (i.e. unsuitable for land application) are

301 associated with industrial wastewater and chlorinated chemical production, in

302 particular, with the industrial use of PCP and sodium-pentachlorophenate. There is a

303 difference in the concentration of dioxin-like compounds between urban and rural

304 samples with no adequate explanation, apart from speculation about industrial inputs.

305 Various studies have shown that this link to industrial inputs is tenuous and the

306 dioxin-like contamination may arise from another source. Horstmann et al. (1993)

307 identified that household wastewater was a significant contributor to dioxin-like

308 compounds in sludge and attributed it to the use of PCP within the textile industry,

309 which is based on the finding that clothing contaminated with dioxin-like compounds

310 can account for the majority of dioxin-like compounds observed in sludge compared

311 to other sources. To date there has been no adequate explanation of the low burden of

312 dioxin-like compounds and its ubiquitous presence in sewage sludge (OCDD $<1000$

$313 \mathrm{ng} \mathrm{kg}{ }^{-1}$ ). There is limited evidence that dioxin-like compounds may be formed in situ

314 or some other unidentified pathway. The fact that PCDD/F were present in sludge at

315 similar levels in New York in 1933 and 1981 suggests the source of these compounds

316 had been introduced by this period in history, which could be related to

317 industrialisation or urbanisation (Lamparski et al., 1984). Other studies have also

318 reported dioxin-like compounds from archived samples and their origin, as yet, cannot

319 be explained (Muller et al., 2004).

320 In the light of this literature review we've undertaken a study to understand the typical

321 levels of dioxin-like compounds in Australian sewage sludge. The literature review

322 will allow us to place the results of this Australian sludge survey into an appropriate

323 context. 


\section{Methods}

325 Two different studies of dioxin-like compounds in Australian sewage sludge were

326 undertaken. They were investigations of (a) dioxin-like compounds in an Australian

327 sewage sludge survey that was conducted in 2006 and (b) the levels of dioxin-like

328 compounds measured at three WWTPs between the years 2002 and 2006.

329 All samples from both studies were analyzed at the National Measurement Institute in 330 Sydney, Australia. The analysis was commissioned by various water utilities and the 331 authors of this report. Sludge samples were extracted using accelerated solvent 332 extraction (ASE) and the extracts were subsequently treated with concentrated 333 sulfuric acid, treated for inorganic and organic sulfur by copper and silver nitrate 334 clean-up techniques respectively and then chromatographically purified using a 335 commercial automated clean-up procedure $\left(\right.$ PowerPrep $\left.^{\mathrm{TM}}\right)$. Analyses were undertaken

336 for PCDDs/PCDFs and dioxin-like PCBs using isotope dilution capillary gas 337 chromatography-electron impact high-resolution mass spectrometry with monitoring 338 of either $\mathrm{M}+,[\mathrm{M}+2]+$ or $[\mathrm{M}+4]+$ ions. The analytical procedure was based upon 339 standard U.S. EPA methodologies (U.S. EPA, 1994).

340 Instrument: GC HP 6890 coupled to Finnigan MAT 95XL HRMS. Regular analysis 341 is performed with a Phenomenex ZB-5MS column $(60 \mathrm{~m} \times 0.25 \mathrm{~mm} \times 0.25 \mu \mathrm{m})$ and 342 confirmation is performed using a J\&W Dbdioxin column $(60 \mathrm{~m} \times 0.25 \mathrm{~mm} \times$ $3430.15 \mu \mathrm{m})$. Injector Temperature $300^{\circ} \mathrm{C}(\mathrm{ZB}-5 \mathrm{MS}) 270^{\circ} \mathrm{C}$ (DB-Dioxin) Injection

344 Volume $1 \mu \mathrm{L}$ splitless. Carrier Gas Helium, run under constant flow mode.

345 Temperature Program DB-5: $100^{\circ} \mathrm{C}$ for $1 \mathrm{~min}$, ramp $40^{\circ} \mathrm{C} / \mathrm{min}$ to $200^{\circ} \mathrm{C}$, ramp $3463.0^{\circ} \mathrm{C} / \mathrm{min}$ to $235^{\circ} \mathrm{C}$, hold for $10 \mathrm{~min}$, ramp $5.0^{\circ} \mathrm{C} / \mathrm{min}$ to $310^{\circ} \mathrm{C}$, hold for $9 \mathrm{~min}$. DB347 Dioxin: $120^{\circ} \mathrm{C}$ for $1 \mathrm{~min}$, $\operatorname{ramp} 50^{\circ} \mathrm{C} / \mathrm{min}$ to $220^{\circ} \mathrm{C}$, ramp $2.5^{\circ} \mathrm{C} / \mathrm{min}$ to $270^{\circ} \mathrm{C}$, hold 348 for $35 \mathrm{~min}$. Transfer Line $280^{\circ} \mathrm{C}$ (DB-5) $250^{\circ} \mathrm{C}$ (DB-Dioxin) MS Parameters Ion 
349 Source: $240^{\circ} \mathrm{C}$, Filament Current: $0.7 \mathrm{~mA}$, Electron Multiplier Voltage: Set to

350 produce a gain of $10^{6}$. Resolution is checked at the beginning and end of each

351 sequence to ensure that the final resolution is not less than 10,000 .

352

353

354

\subsection{Australian Sewage Sludge Survey 2006}

An Australian survey of sewage sludge from operational WWTPs $(n=14)$ was conducted. The fourteen samples were collected from each state (and the Northern Territory) of Australia during 2006 from both urban (population $>1,000,000$ ) and rural WWTPs (population $<300,000$ ). The samples were collected in pre-cleaned amber glass jars with Teflon lined lids. The samples were collected by the various WWTP personal and sent via courier to the National Measurement Institute for analysis. Table 2 provides data on the population for each WWTP sampled and a description of the type of treatment process.

\subsection{Dioxin-like compounds Variation with Time}

Two sewage sludge samples were collected and analyzed for dioxin-like compounds from three WWTPs in Western Australia in the years 2002, 2003, 2005 and 2006.

These samples were collected in pre-cleaned amber glass jars with Teflon lined lids.

The samples were collected by the various WWTP personal and sent via courier to the laboratory. Table 3 lists the WWTPs from which sewage sludge were analyzed for dioxin-like compounds in the target years.

\subsection{Statistical Analysis}

Principle component analysis was performed to analyse the relationship among the dioxin-like compounds using the software package NTSYSpc version 2.20 (Exeter Software). The raw concentration data for each compound were standardised to mean zero and standard deviation and the PCA conducted on the correlation matrix. Values 
373 below the detection limit were assumed to be zero for this analysis. Separate principal

374 component analyses were conducted for all the dioxin-like compounds, the dioxin-

375 like PCDD/Fs, and for the dioxin-like PCBs separately. The treatment plant scores for

376 the first principal axis were then regressed on population to test for a relationship

377 between that component and urban community size or urban versus rural sources.

378 In the study of variation in dioxin-like compounds over time, covariance analysis was

379 used to test whether there was a linear trend in TEQ over time and whether the

380 relationship was different for the three WWTPs.

\section{Results and Discussion}

382 All sludge samples analysed have a low burden of dioxin-like compounds. TEQ

383 results can be reported with (middle-bound) and without 'half the detection limit'

384 (lower-bound). The detection limit is provided within the table of results but has not

385 been used in calculation of the lower bound TEQs. The reproducibility of analysis and

386 sampling methodology was tested by analysis of WWTP B sample in triplicate. The

387 relative standard deviations ranged from 3 to $35 \%$ for the dioxin-like compounds and

388 there was a $17 \%$ variation of the $\mathrm{WHO}_{05}$ TEQ value calculated $(15.3,16.8$ and 12.1

$389 \mathrm{WHO}_{05}$ TEQ ng kg-1).

\subsection{Australian Sewage Sludge Survey 2006}

391 The raw data of the Australian sewage sludge 2006 survey are presented within Table

392 4. Reported are the results of individual dioxin-like congeners. The toxicity

393 equivalence (TEQ) has been calculated in all three major schemes (I-TEQ, WHO 98

394 TEQ and $\mathrm{WHO}_{05}$ TEQ) as well as the TEQ contribution from the dioxin-like

395 PCDD/Fs and the dioxin-like PCBs. The concentration of homologues has also been

396 provided. 
The lower bound sludge concentrations ranged between 1.2 and $16.8 \mathrm{WHO}_{05}$ TEQ ng

$398 \mathrm{~kg}^{-1}$. Twelve of the fourteen samples had 2,3,7,8-TCDD less than the detection limit

399 and the samples with measurable concentrations were 0.772 and $1.6 \mathrm{ng} \mathrm{kg}^{-1}$. These

400 results compare favourably with similar studies conducted in other countries, the

401 proposed international and domestic guidelines, and the background levels of dioxin-

402 like compounds in the Australian environment as discussed in the DEH's "National

403 Dioxin Program" (Muller et al., 2004). In fact, the majority of samples had dioxin-

404 like compounds within the range of soil levels in Australia; 0.05-23 WHO 98 TEQ ng

$405 \mathrm{~kg}^{-1}$ d.w. middle-bound concentration (Muller et al., 2004). The soil samples also had 406 a similar congener profile to that of sludges, which are dominated by OCDD (Muller 407 et al., 2004).

408 There was a difference observed between mean congener concentration when

409 comparing urban and rural samples. The mean concentration of all the $2,3,7,8$ -

410 substituted congeners was lower for the rural samples compared to the urban samples

411 and 5 of the highest 6 concentration were observed in urban sludges. While the urban

412 mean may be skewed due to higher concentrations of dioxin-like compounds from

413 WWTP A, these higher concentrations of dioxin-like compounds appear to be more

414 typical of urban sludge concentrations (based upon the scientific literature). The

$415 \mathrm{WHO}_{05}$ TEQ was higher for the urban samples with 6.9 (s.d. 4.5) compared to 4.6

416 (s.d. 4.6) $\mathrm{WHO}_{05}$ TEQ ng kg-1.

417 A positive correlation between OCDD concentration and TEQ systems was found; I-

418 TEQ $\mathrm{R}=0.97, \mathrm{WHO}_{98} \mathrm{TEQ} \mathrm{R}=0.70, \mathrm{WHO}_{05}$ TEQ $\mathrm{R}=0.82$. An extremely strong

419 correlation $(\mathrm{R}=0.95)$ was found between the compounds OCDD and OCDF.

420 Principal component analysis was performed on (1) the dioxin-like PCDD/Fs, (2) the 421 dioxin-like PCBs (Fig. 1a and 1b) and (3) all the dioxin-like compounds (Figure not 
shown). For the dioxin-like PCDD/Fs the first three eigenvalues were $64.5 \%, 11.4 \%$ and $7.9 \%$ so the biplot (Fig. 1a) in the first two dimensions retains $76 \%$ of the total sum of squares of the original data and should provide a very good representation of

425 the relationships between the compounds and the sampled WWTPs. All the dioxin-

426 like compounds were found to be positively correlated to the first principal axis 427 (PCA-I) and all contributed to a similar degree to variation in the two-dimensional 428 space represented in the biplots (i.e. vectors of similar length). Inspection of the 429 eigenvectors indicates that the first principal axis represents overall concentration of 430 the dioxin-like PCDD/Fs while the second axis (PCA-II) is a contrast between $431 \mathrm{OCDD} / \mathrm{OCDF}$ and 2378-TCDF/12378-PeCDD/123678-HxCDD/123789-HxCDD. 432 WWTP A has the highest overall concentration of PCDD/Fs and WWTP A has 433 relatively high OCDD/OCDF. Data for 2,3,7,8-TCDD were not included in this 434 analysis as concentrations were below the detection threshold in most samples.

\section{FIGURE 1 NEAR HERE}

The PCA analysis of the dioxin-like PCBs (without PCB 169 as it was generally below the detection threshhold) was even more strongly dominated by one dimension

438 than that for the dioxin-like PCDD/Fs, with the first two eigenvalues being $83.8 \%$ and $4397.7 \%$. The biplot on the first two principal axes (Fig. 1b) retains $92 \%$ of the original 440 variation. The first principal axis represents average concentration of the dioxin-like 441 PCBs while the second principal axis represents differing composition, essentially a 442 contrast between PCB81 (and to an extent PCB77) and the group of PCBs with 443 PCB156, but variation along this axis is not very important relative to that on the first 444 axis. The curved pattern of the WWTPs in the biplot indicates that their positions in 445 the original space is could be summarised even more effectively in only one 446 dimension by a non-linear ordination technique such as non-metric multidimensional 
scaling but this would not have shown the relationships among the dioxin-like PCBs as effectively.

449 The positions of the treatments plants are generally similar in both ordinations.

450 Unsupervised PCA also revealed clusters that appeared to coincide roughly to urban

451 vs rural, with a few exceptions such as WWTP B that had a relatively high burden of

452 dioxin-like compounds. WWTP B has a low population $(142,000)$ and is in a region

453 where previously there was a large smelting industry, which is a known source of

454 dioxin-like compounds (IPCS, 1989). Another exception is WWTP N, which had a

455 higher dioxin-like PCDD/F burden than expected and therefore also had a high PCAI

456 score. WWTP N is in a geographically isolated area, has a very low population

$457(14,000)$ and no known industrial emitters dioxin-like compound and its relatively

458 high burdens are unexplained. However the dioxin-like PCBs PCA1 score was also

459 high for WWTP N, which may explain the higher burden of dioxin-like PCDD/Fs.

460 One possible explanation is that PCBs may have been inappropriately disposed of in

461 the area causing elevated concentrations of dioxin-like PCDD/Fs as well as dioxin-

462 like PCBs. A plot of PCAI vs population for the dioxin-like PCDD/Fs indicated a

463 generally positive association with one unusual point, WWTP B (Fig. 2). If WWTP B

464 is left out then the regression of PCAI on population size is highly statistically

465 significant $(\mathrm{P}<0.01)$. The trend line shown in Fig. $2 \mathrm{a}$ is the linear regression

466 omitting point $\mathrm{B}$. PCAI effectively summarises overall PCDD/F concentration so

467 there is a general positive relationship between dioxin-like PCDD/F burden in sewage

468 sludge and population. An equivalent graph of the PCBs PCAI against population

469 indicated a weaker relationship (Fig. 2b). WWTP B was again an unusual point,

470 having a much higher PCAI score than other plants in population centres of similar

471 size, but WWTP N also had a very high score. If WWTP B is deleted from the 
472 analysis there is a significant $(\mathrm{P}=0.042)$, positive regression and this trend line is 473 shown in the Fig. 2 b.

The burden of dioxin-like compounds increases with population, and this is likely to

476 be related to urbanisation and not specifically population. This source of dioxin-like

477 compounds in the urban environment must also have been present in 1933, given that

478 similar levels have been detected in an archived sludge sample (Lamparski et al., 479 1984), as well as one archived Australian soil sample of the same period (Muller et 480 al., 2004). The correlation of dioxin-like PCDD/Fs with dioxin-like PCBs suggests 481 that these compounds are also being produced and emitted by the same, as yet, un482 identified source. All the Australian sewage sludge samples cited in this study are 483 below the Victorian EPA “investigation limit” of $50 \mathrm{WHO}_{98}$ TEQ ng kg ${ }^{-1}$, well below 484 the European proposed guidelines of $100 \mathrm{WHO}_{98}$ TEQ $\mathrm{ng} \mathrm{kg}^{-1}$, and also below the 485 most stringent international guidelines e.g. the Canadian guideline of $27 \mathrm{WHO}_{98} \mathrm{TEQ}$ $486 \mathrm{ng} \mathrm{kg}^{-1}$. The mean concentration of dioxin-like compounds in sewage sludge in this 487 survey is $5.6 \mathrm{WHO}_{05}$ TEQ $\mathrm{ng} \mathrm{kg}^{-1}$.

\subsection{Dioxin-like Compounds Variation with Time}

489 In the study of Western Australian sludge samples there was little change in the 490 concentration of dioxin-like compounds during the years 2002-2006. As found in 491 other studies OCDD, OCDF and 1,2,3,4,6,7,8-HpCDD were the dominant congeners 492 present. The concentration of dioxin-like compounds within this study ranged from 4932.5 to $20.6 \mathrm{WHO}_{05}$ TEQ $\mathrm{ng} \mathrm{kg}^{-1}$. Generally speaking this is slightly higher than the 494 national mean of $5.6 \mathrm{WHO}_{05}$ TEQ $\mathrm{ng} \mathrm{kg}^{-1}$. Table 5 presents the concentration of 495 individual congeners and presents the concentration of each homologue. 
Independent linear regressions of $\mathrm{WHO}_{05}$ TEQ on year for each treatment plant, a

497 single slope but independent intercepts, and a single overall regression were tested in

498 an analysis of covariance. There was no evidence for differences in either slope or

499 intercept among treatment plants but the single overall regression was highly

500 significant $(\mathrm{P}<0.01)$. On average $\mathrm{WHO}_{05}$ TEQ declined by $1.49 \mathrm{ng} \mathrm{kg}^{-1}$ each year.

501 The data and the fitted regression line are shown in Figure 3. There was markedly

502 more variation between samples in 2002 and 2005. There is a large variation in the

$503 \mathrm{WHO}_{05}$ TEQ in the years 2002 and 2005, particularly when compared to 2003 and

504 2006, which have very similar results (Fig. 3). This suggests that the flux of dioxin-

505 like compounds in sewage sludge is associated with a random event (i.e. such as

506 bushfires) rather than industrial. It is expected that industrial emitters of dioxin-like

507 compounds would be consistent in their industrial processes and emissions.

508 FIGURE 3 NEAR HERE

\subsection{General Discussion}

510 There has been a variety of different systems for reporting the results of chlorinated

511 dioxins and furans as well as the dioxin-like PCBs and this can make comparison of

512 historical data difficult. One compound that has been routinely monitored and

513 reported is OCDD, and it is suggested that this compound could be a marker for

514 contamination to facilitate discussion and comparison of historical and contemporary

515 data, even as TEQ systems continue to evolve. From our data set we have found a

516 positive correlation between OCDD concentration and TEQ systems; I-TEQ R $=0.97$,

$517 \mathrm{WHO}_{98}$ TEQ $\mathrm{R}=0.70, \mathrm{WHO}_{05}$ TEQ $\mathrm{R}=0.82$. This correlation has also been

518 identified by Fuentes et al who included the contribution of OCDF to predict the I-

519 TEQ burden (Fuentes et al., 2007). In our data set all the dioxin-like PCDD/Fs and

520 PCBs were positively correlated. In fact principle component analysis revealed that 
that the total variation was mainly due to overall differences in overall load of dioxinlike compounds, with differences in relative concentrations of individual compounds contributing only a minor component to the overall variation between sludges.

Effectively the variation in dioxin-like compounds in sewage sludge can be summarised in just a single dimension, i.e. the total concentration of dioxin-like compounds. Furthermore OCDD is a good choice of dioxin-like compound marker as its magnitude relative to other dioxin-like compounds means the variance in reported concentrations is far lower than other dioxin-like compounds with smaller magnitudes. Therefore, a crude classification of sewage sludge contamination based upon OCDD concentration is proposed (See Table 6). Equivalent I-TEQ have been calculated using I-TEQ ng kg-1 $=0.053\left(\mathrm{OCDF}_{\mathrm{ng} \mathrm{kg}}{ }^{-1} \text { d.w. }\right)^{0.36}\left(\mathrm{OCDD} \mathrm{ng} \mathrm{kg}^{-1}\right.$ d.w.) ${ }^{0.49}$ (Fuentes et al., 2007); OCDF concentrations were estimated based upon the average ratio of OCDD to OCDF from our survey data.

\section{Conclusions}

A general positive relationship was found between population of the town producing the waste and both dioxin-like PCDD/Fs and dioxin-like PCBs. The one exception to this trend was sludge from a town that had a history of smelting that had a relatively high burden of dioxin-like compounds. Sludge from WWTP N also had a higher burden of dioxin-like compounds. The treatment plant services a geographically isolated town with a low population and no known emitters of dioxin-like compounds. However, this sample also had a relatively high burden of dioxin-like PCBs, which could be the source of the dioxin-like PCDD/Fs found in this sludge.

All sewage sludge samples analysed as part of these studies had low overall concentrations of dioxin-like compounds. Out of thirty-seven samples, all except one, were within the reported concentration range of soil within the Australian 
546 environment $\left(0.05-23 \mathrm{WHO}_{98}\right.$ TEQ $\mathrm{ng} \mathrm{kg}^{-1}$ middle bound concentration) (Muller et 547 al., 2004). The mean concentration of dioxin-like compounds in Australian sewage 548 sludge survey of 2006 was found to be 5.6 (s.d. 4.5) $\mathrm{WHO}_{05}$ TEQ $\mathrm{ng} \mathrm{kg}^{-1}(\mathrm{n}=14)$ and

549 were within the range of 1.2 to $15.3 \mathrm{WHO}_{05}$ TEQ ng kg${ }^{-1}$. All the Australian sewage 550 sludge samples cited in these studies were below the Victorian EPA "investigation 551 limit" of $50 \mathrm{WHO}_{98}$ TEQ $\mathrm{ng} \mathrm{kg}^{-1}$, well below the European proposed guidelines of $552100 \mathrm{WHO}_{98}$ TEQ ng kg${ }^{-1}$, and also below the most stringent guidelines internationally 553 i.e. Canada's 27 I-TEQ $\mathrm{ng} \mathrm{kg}^{-1}$. The burden of dioxin-like compounds is Australian 554 sewage sludge is low and its land application as biosolids is not likely to pose a 555 problem.

\section{Acknowledgements}

557 The authors would like to acknowledge the water treatment authorities that kindly 558 supplied data and samples and permitted it to be released publicly. BC gratefully 559 acknowledges the financial support of Wastewater Program of the CRCWQT, the

560 Water Corporation of Western Australian and the Victorian Department of Human 561 Services.

\section{References}

563 Alvarado, M.J., Armstrong, S., Crouch, E., 2001. The AMSA 2000/2001 Survey of 564 Dioxin-like Compounds in Biosolids: Statistical Analyses. Cambridge Environmental, 565 Inc.

566 Dai, J., Xu, M., Chen, J., Yang, X., Ke, Z., 2007. PCDD/F, PAH and heavy metals in 567 the sewage sludge from six wastewater treatment plants in Beijing, China.

568 Chemosphere 66, 353. 
569 DEH, 2005. National dioxins program - dioxins in Australia: A summary of the

570 findings of studies conducted from 2001 to 2004 Australian Government: Department

571 of the Environment and Heritage, Canberra.

572 EPA Victoria, 2004. Guidelines for Environmental Management - Biosolids Land

573 Application. Melbourne.

574 European Commission, 2001. Organic Contaminants in Sewage Sludge For

575 Agricultural Use. In: Langenkamp, H., Part, P. (Eds.). European Commission Joint

576 Research Centre Institute for Environment and Sustainability Soil and Waste Unit.

577 European Union, 2001. Working Document on Sludge: 3rd Draft. Brussels.

578 Fuentes, M.J., Font, R., Gomez-Rico, M.F., Molto, J., 2007. Multivariant statistical

579 analysis of PCDD/FS in sewage sludges from different areas of the Valencian

580 Community (Spain). Chemosphere 67, 1423-1433.

581 Hagenmaier, H., Brunner, H., Haag, R., Berchtold, A., 1986. PCDDs and PCDFs in

582 sewage sludge, river and lake sediments from south west Germany. Chemosphere 15, $583 \quad 1421-1428$.

584 Horstmann, M., McLachlan, M.S., 1995. Concentrations of Polychlorinated Dibenzo585 p-Dioxins (PCDD) and Dibenzofurans (PCDF) in urban runoff and household

586 wastewaters. Chemosphere 31, 2887-2896.

587 Horstmann, M., McLachlan, M.S., Reissinger, M., 1993. Investigations of the origin 588 of PCDD/F in municipal sewage sludge. Chemosphere 27, 113-120.

589 IPCS, 1989. Environmental Health Criteria 88: Polychlorinated Dibenzo-p-Dioxins 590 and Dibenzofurans. International Programme on Chemical Safety

591 Jensen, S., 1972. The PCB Story. Ambio 1, 123-131. 
Klimm, C., Schramm, K.W., Henkelmann, B., Martens, D., Kettrup, A., 1998.

593 Formation of Octa- and heptachlorodibenzo-p-dioxins during semi anaerobic

594 digestion of sewage sludge. Chemosphere 37, 2003.

595 Kutz, F.W., Barnes, D.G., Bottimore, D.P., Greim, H., Bretthauer, E.W., 1990. The

596 international toxicity equivalency factor (I-TEF) method of risk assessment for

597 complex mixtures of dioxins and related compounds. Chemosphere 20, 751-757.

598 Lamparski, L.L., Nestrick, T.J., Stenger, V.A., 1984. Presence of chlorodibenzo

599 dioxins in a sealed 1933 sample of dried municipal sewage sludge. Chemosphere 13,

600361.

601 Muller, J., Muller, R., Goudkamp, K., Shaw, M., Mortimer, M., Haynes, D.,

602 Burniston, D., Symons, R., Moore, M., 2004. Dioxins in Soils in Australia. National

603 Dioxins Program Technical Reports No. 5. Australian Government, Department of the

604 Environment and Heritage, Canberra.

605 NRMMC, 2004. National Water Quality Management Strategy - Guidelines for

606 Sewerage Systems: Biosolids Management. Department of the Environment and

607 Water Resources, Australian Government, Canberra.

608 Oberg, L.G., Rappe, C., 1992. Biochemical formation of PCDD/Fs from

609 chlorophenols. Chemosphere 25, 49-52.

610 Rappe, C., Andersson, R., 1992. Levels of PCDDs and PCDFs in Human Feces.

611 Organohalogen Compounds 9, 195-198.

612 Rappe, C., Andersson, R., Bonner, M., Cooper, K., Fiedler, H., Howell, F., 1998.

613 PCDDs and PCDFs in municipal sewage sludge and effluent from potw in the state of

614 Mississippi, USA. Chemosphere 36, 315-328. 
615 Rappe, C., Andersson, R., Karlaganis, G., Bonjour, R., 1994. PCDDs and PCDFs in

616 Samples of Sewage Sludge from Various Areas in Switzerland. Organohalogen

617 Compounds 20, 79-84.

618 Rappe, C., Andersson, R., Studer, C., Karlaganis, G., 1997. Decrease in the

619 Concentration of PCDDs and PCDFs in Sewage Sludge from Switzerland.

620 Organohalogen Compounds 33, 82-87.

621 Rappe, C., Kjeller, L.-O., Andersson, R., 1989. Analyses of PCDDs and PCDFs in

622 sludge and water samples. Chemosphere 19, 13-20.

623 Rivera, J., Eljarrat, E., Espadaler, I., Martrat, M.G., Caixach, J., 1997. Determination

624 of PCDF/PCDD in sludges from a drinking water treatment plant influence of

625 chlorination treatment. Chemosphere 34, 989.

626 Stevens, J., Green, N.J.L., Jones, K.C., 2001. Survey of PCDD/Fs and non-ortho

627 PCBs in UK sewage sludges. Chemosphere 44, 1455.

628 Telliard, W.A., McCarty, H.B., King, J.R., Hoffman, J.B., 1990. USEPA National

629 Sewage Sludge Survey Results For Polychlorinated Dibenzo-p-Dioxins and

630 Polychlorinated Didenzofurans. Organohalogen Compounds 2, 307-310.

631 U.S. EPA, 1994. Method 1613: Tetra- through Octa- Chlorinated Dioxins and Furans

632 by Isotope Dilution HDGC/HRMS. U.S. Environmental Protection Agency -

633 Engineering and Analysis Division Washington.

634 U.S. EPA, 2003. Federal Register: Part III Environmental Protection Agency -

635 Standards for the Use or Disposal of Sewage Sludge: Decision Not to Regulate

636 Dioxins in Land-Applied Sewage Sludge. U.S. Environmental Protection Agency.

637 Van den Berg, M., Birnbaum, L., Bosveld, A.T.C., Brunstrom, B., P.Cook, Feely, M.,

638 Giesy, J.P., Hanberg, A., Hasegawa, R., Kennedy, S.W., Kubiak, T., Larsen, J.C.,

639 Leeuwen, F.X.R.c., Liem, A.K.D., Nolt, C., Peterson, R.E., Poellinger, L., Safe, S., 
640 Schrenk, D., Tillitt, D., Tysklind, M., Younes, M., Waern, F., Zacharewski, T., 1998.

641 Toxic Equivalency Factors (TEFs) for PCBs, PCDDs, PCDFs for Humans and

642 Wildlife. Environ. Health. Persp. 106.

643 Van den Berg, M., Birnbaum, L.S., Denison, M., Vito, M.D., Farland, W., Feeley, M., 644 2006. Review: The 2005 World Health Organization Reevaluation of Human and 645 Mammalian Toxic Equivalency Factors for Dioxins and Dioxin-Like Compounds. 646 Toxicol. Sci. 93, 223-241.

647 Wendling, J.M., Orth, R.G., Poiger, H., Hileman, F.D., 1990. Methodology for the 648 analysis of 2,3,7,8-tetrachlorodibenzo-p-dioxin in feces. Chemosphere 20, 343-347. 649 650 


\section{Table 1}

Concentration of 2,3,7,8-tetrachlorodibenzo-p-dioxin (2,3,7,8-TCDD), octachlordibenzo-p-dioxin (OCDD) and toxicity equivalence (I-TEQ or WHO 98 TEQ) in international sewage sludge as reported in scientific literature relating to dioxin-like compounds in sewage sludge

\begin{tabular}{|c|c|c|c|c|}
\hline Nation & Author Year & 2,3,7,8-TCDD ng kg-1 & OCDD ng kg ${ }^{-1}$ & TEQ (I-TEQ or WHO (I8 $_{\text {TEQ) }}$ ng kg $^{-1}$ \\
\hline America & Lamparski et al. 1984 & $\begin{array}{l}1933-2.2 \\
1981-11 \\
1982-16\end{array}$ & $\begin{array}{l}1933-59000 \\
1981-50,000 \\
1982-60,000\end{array}$ & \\
\hline America & Weerasinghe et al.1985 & & $60,0007,600$ & \\
\hline Germany & Hagenmaier et al. 1986 & & 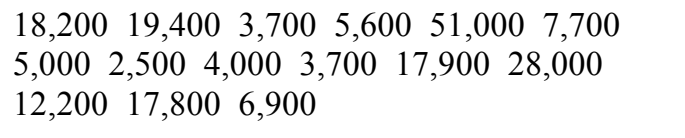 & \\
\hline Sweden & Rappe et al. 1989 & $0.72<0.48$ & $9,1007,400$ & \\
\hline Sweden & Broman et al. 1990 & $\begin{array}{llll}1.5 & 2.2 & 1.7 & 1.3\end{array}$ & $\begin{array}{llll}328,644 & 16,354.4 & 30,765.7 & 12,829.2\end{array}$ & \\
\hline Canada & Ho et al. 1990 & & 0.6 to $309 \mathrm{n}=99$ & \\
\hline Sweden & Naf et al. 1990 & 1 & 750 & \\
\hline Germany & Hagenmaier et al. 1992 & & & 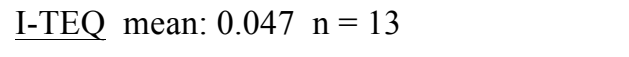 \\
\hline Switzerland & Rappe et al. 1994 & & $\begin{array}{lllllll}5,700 & 4,300 & 5,000 & 1,400 & 17,000 & 24,000 \\
22,00 & 26,000 & 4,900 & 9,800 & 14,000 & 5,400 \\
5,700 & 19,000 & 8,600 & 11,000 & 67,000 & 19,000 \\
3,300 & 15,000 & 4,300 & 630 & 3,800 & 8,500 & 24,000 \\
20,000 & 51,000 & 360 & 20,000 & 27,000\end{array}$ & 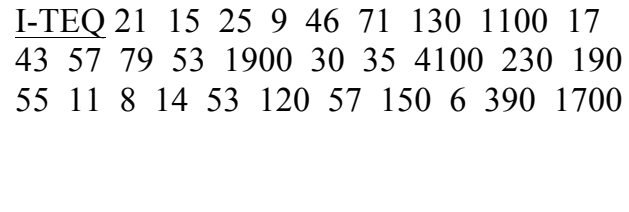 \\
\hline United Kingdom & Sewart et al. 1995 & $\begin{array}{llllllll}1.9 & 3.8 & 1.4 & 2.9 & 1.0 & 2.1 & 1.0 \\
2.9 & & & & & & & \end{array}$ & $\begin{array}{llllll}11,000 & 23,200 & 650 & 63,000 & 6,500 & 15,400 \\
7,500 & 1,820\end{array}$ & $\begin{array}{llllllll}\text { I-TEQ } 29 & 29 & 23 & 0.7 & 9.9 & 29 & 15 & 0.4\end{array}$ \\
\hline
\end{tabular}


Switzerland

Rappe et al. 1997

America

Rappe et al. 1998

Spain

Eljarrat et al. 1999

United Kingdom Stevens et al. 2001

Canada

Spain

China

Spain

Bright et al. 2003

Eljarrat et al. 2003

Dai et al. 2007

Fuentes et al. 2007 $\begin{array}{llllll}<1.5 & <0.12 & 1.7 & 0.65 & 1.2 & 0.31\end{array}$

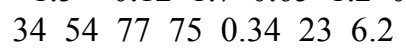
$0.27<4.2 \quad 0.75$

$\begin{array}{llllll}2.1<0.06 & 2.0 & 0.84 & 1.9 & 0.17\end{array}$

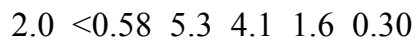
$\begin{array}{llllll}<0.13 & 0.17<0.051 & 0.076 & 1.0\end{array}$ $<0.35$

$\begin{array}{lllllll}1.5 & 0.8 & 0.4 & \text { ND ND } & 1.0 & 4.6\end{array}$ $\begin{array}{lllllll}1.5 & \text { ND } & 0.5 & 1.9 & 1.1 & 0.6 & 0.6\end{array}$ $\begin{array}{lllll}\text { ND } & 1.0 & 3.8 & 0.5 & 8.7\end{array}$

$\begin{array}{lllllll}1.1 & 5.6 & 1.6 & 2.6 & 3.3 & 0.8 & 1.6\end{array}$ $\begin{array}{lllllll}0.8 & 0.7 & 1.0 & 2.1 & 1.2 & 1.0 & 1.1\end{array}$

range: 0.3 to 3.9 mean: $1.1 \mathrm{n}=$ 26

$\mathrm{f}=100 \%$

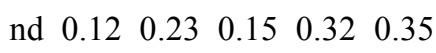
0.390 .20

$7.61<0.17<0.18<0.10$

$<0.14<0.08$

$\begin{array}{llllllll}0.5 & 0.4 & 0.3 & 0.1 & 1.2 & 0.7 & 0.6\end{array}$ $\begin{array}{lllllll}0.86 & 25 & 2.2 & 5.8 & 0.91 & 0.92 & 1.3\end{array}$

$\begin{array}{lllllll}4,300 & 1,400 & 5,700 & 1,800 & 22,000 & 870 & 26,000\end{array}$ $\begin{array}{lllllll}27,000 & 5,400 & 19,000 & 650 & 67,000 & 20,000 & 890\end{array}$

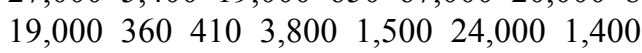
$51,000 \quad 2,200$

$\begin{array}{lllllll}7,400 & 7,400 & 4,300 & 1,800 & 7,700 & 2,700 & 9,300\end{array}$ $\begin{array}{llllll}6,800 & 480,000 & 420,000 & 3,500 & 3,300 & 1,400\end{array}$

$\begin{array}{lllll}1,900 & 560 & 2,600 & 4,400 & 27,000\end{array}$

$\begin{array}{lllllll}5,700 & 2,000 & 4,600 & 2,500 & 5,100 & 7,800 & 6,000\end{array}$ $\begin{array}{llllll}15,000 & 9,600 & 1,100 & 1,600 & 2,000 & 1,000\end{array}$ $\begin{array}{llllll}19,000 & 4,700 & 3,800 & 3,9500 & 4,900 & 1,800\end{array}$

$\begin{array}{llllll}4,460 & 51,500 & 2,990 & 3,120 & 31,400 & 4,150\end{array}$ $\begin{array}{lllllll}9,990 & 6,280 & 13,500 & 2,320 & 2,900 & 3,020 & 4,800\end{array}$ 2,610 $\begin{array}{lllllll}0.6 & 0.5 & 0.5 & 0.4 & 0.2 & 0.2 & 0.3\end{array}$ $\begin{array}{lllllll}0.4 & 3.0 & 0.8 & 0.62 & 1.3 & 0.6 & 1.4\end{array}$

$\begin{array}{lllllll}1.9 & 1.3 & 1.5 & 1.0 & 1.0 & 0.4 & 0.5\end{array}$

$\begin{array}{lll}1.3 & 0.2 & 0.1\end{array}$ range: 730 to 16,000 mean: 4,500

$\mathrm{n}=26 \mathrm{f}=100 \%$

$852 \quad 527 \quad 785 \quad 609943 \quad 647556 \quad 1603$

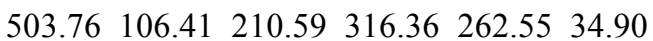

$\begin{array}{lllllll}2220.8 & 1796.1 & 852.2 & 830.8 & 1172.3 & 1677.7\end{array}$ $\begin{array}{lllllll}1666.1 & 773.5 & 827.9 & 1875.4 & 774.8 & 1396.5\end{array}$ $\begin{array}{llllll}1470.6 & 816.3 & 976.2 & 866.3 & 820.0 & 2285.5\end{array}$ $\begin{array}{lllllll}705.3 & 550.7 & 204.3 & 167.7 & 4470.6 & 3047.5\end{array}$ $\begin{array}{lllll}4074.9 & 7279.1 & 27306.8 & 1991.3 & 1679.9\end{array}$ $2262.0 \quad 1469.2$
I-TEQ $15 \quad 9.7 \quad 21 \quad 8.4 \quad 130 \quad 10 \quad 12001700$ $\begin{array}{lllllllll}2200 & 1900 & 16 & 1400 & 390 & 22 & 230 & 6.2 & 120\end{array}$ $\begin{array}{lllllllll}14 & 6.1 & 120 & 14 & 6.1 & 120 & 15 & 150 & 23\end{array}$

I-TEQ $23.7 \quad 27.6 \quad 26.4 \quad 13.7 \quad 30.9 \quad 4.83$ $\begin{array}{llllllll}36.7 & 37.7 & 1270 & 1240 & 31.7 & 7.40 & 2.67 & 6.18\end{array}$ $\begin{array}{llll}2.26 & 3.35 & 33 & 70.4\end{array}$

I-TEQ $23 \quad 23 \quad 24 \quad 6.9 \quad 43 \quad 58 \quad 70 \quad 150 \quad 86$ $\begin{array}{llllllllll}7.8 & 13 & 14 & 51 & 130 & 18 & 46 & 160 & 14 & 110\end{array}$

$\begin{array}{lllllll}\text { I-TEQ } 53.4 & 225 & 49.2 & 23.0 & 153 & 19.9 & 40.5\end{array}$ $\begin{array}{lllllll}30.2 & 45.1 & 40.3 & 29.2 & 24.7 & 152 & 19.9\end{array}$

range: I-TEQ 5.5 to 250 mean: 40 $\mathrm{n}=26 \mathrm{f}=100 \%$

$\underline{\text { WHO }}_{98}$ TEQ $20.8 \quad 5.43 \quad 7.18 \quad 4.90 \quad 6.92$ $8.067 .18 \quad 14.1$

I-TEQ $88.24 \quad 3.47 \quad 4.13 \quad 32.80 \quad 5.30 \quad 7.07$

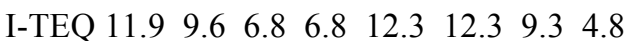
$\begin{array}{lllllllllll}6.3 & 7.6 & 5.1 & 5.6 & 6.3 & 5.9 & 7.1 & 12.9 & 8.8 & 10.1\end{array}$ $\begin{array}{llllllllll}9.3 & 8.2 & 5.1 & 5.1 & 17.1 & 19.5 & 23.6 & 23 & 48.8\end{array}$ 28.735 .643 .6346 
Table 2

Australian Sewage Sludge Survey 2006 - Type of treatment process and source of wastewater

\begin{tabular}{|c|c|c|}
\hline WWTP & Population $^{1}$ & Treatment Method \\
\hline A & $4,297,000$ & Anaerobically digested and freshly dewatered. \\
\hline $\mathrm{B}$ & 142,000 & $\begin{array}{l}\text { Stored in a lagoon for } 6 \text { months. Dewatered by centrifuge and stockpiled } \\
\text { for } 4 \text { months. } 92 \% \text { domestic } 8 \% \text { trade waste. }\end{array}$ \\
\hline $\mathrm{C}$ & 106,000 & Dewatered by vacuum filtration \\
\hline $\mathrm{D}$ & 27,000 & Activated sludge. Dewatered. Domestic source. \\
\hline $\mathrm{E}$ & $1,811,000$ & Dewatered. Composition industrial and domestic. \\
\hline $\mathrm{F}$ & 35,000 & Aerobic digestion. Dewatered. Domestic and light industrial. \\
\hline G & $1,139,000$ & $\begin{array}{l}\text { Activated sludge. Dissolved air-flotation filtration. Mixture of domestic and } \\
\text { industrial and some groundwater runoff. }\end{array}$ \\
\hline $\mathrm{H}$ & $1,139,000$ & $\begin{array}{l}\text { Integrated fixed-film activated sludge. Mixture of domestic and industrial } \\
\text { and some groundwater runoff. }\end{array}$ \\
\hline I & 202,000 & Chemically stabilized with lime. \\
\hline $\mathrm{J}$ & 52,000 & Dewatered and chemically stabilized (lime). Mainly domestic. \\
\hline $\mathrm{K}$ & $3,850,000$ & $\begin{array}{l}\text { Activated sludge plant. Anaerobically digested primary and secondary } \\
\text { sludge. Dewatered in sludge drying pans. Stockpiled for }>3 \text { years. Source } \\
\text { industrial and domestic }\end{array}$ \\
\hline $\mathrm{L}$ & 5,000 & Activated sludge and lagoon process. Land dried. \\
\hline M & $1,508,000$ & $\begin{array}{l}\text { Activated sludge. Mechanically dewatered. Chemically stabilized (lime). } \\
\text { Mainly domestic, } \sim 5 \% \text { industrial. }\end{array}$ \\
\hline $\mathrm{N}$ & 14,000 & Oxidation treatment pond. Solar dried. \\
\hline
\end{tabular}


Table 3

Wastewater treatment plants from Perth, Australia, where sewage sludge samples were collected and analysed for dioxin-like compounds between the years 2002 to 2006

\begin{tabular}{ll}
\hline Beenyup WWTP & $\begin{array}{l}110 \mathrm{ML} / \text { day, mesophilic anerobic digestion, centrifuge dewatering, } 2 \% \\
\text { industrial input }\end{array}$ \\
Subiaco WWTP & $\begin{array}{l}60 \mathrm{ML} / \text { day dewatered and chemically stabilized. Mainly domestic. } \sim 5 \% \\
\text { industrial input }\end{array}$ \\
Woodman Point & $\begin{array}{l}120 \mathrm{ML} / \text { day mesophilic anerobic digestion, centrifuge dewatering, } \sim 9 \% \\
\text { industrial input }\end{array}$ \\
\hline
\end{tabular}

656 
Table 4

Concentration of dioxin-like congeners (ng kg-1 d.w.) in 14 sewage sludge samples collected from Australian sources 2006

\begin{tabular}{|c|c|c|c|c|c|c|c|c|c|c|c|c|c|c|c|c|}
\hline \multirow[b]{2}{*}{ Congeners } & \multicolumn{14}{|c|}{ Wastewater Treatment Plant } & \multirow[b]{2}{*}{ Mean } & \multirow[b]{2}{*}{ Sd } \\
\hline & $\mathbf{A}$ & B & $\mathbf{C}$ & D & $\mathbf{E}$ & $\mathbf{F}$ & $\mathbf{G}$ & $\mathbf{H}$ & I & $\mathbf{J}$ & $\mathbf{K}$ & $\mathbf{L}$ & $\mathbf{M}$ & $\mathbf{N}$ & & \\
\hline $2,3,7,8-\mathrm{TCDF}$ & 2.6 & 3.9 & 2.1 & 0.83 & 1.5 & 1.3 & 1.1 & 1.2 & $<0.4$ & 0.6 & 11 & 0.775 & $<0.6$ & 1.3 & 2.4 & 2.9 \\
\hline 2,3,7,8-TCDD & 1.6 & 0.72 & $<0.3$ & $<0.4$ & $<.5$ & $<0.5$ & $<.6$ & $<0.5$ & $<0.4$ & $<0.4$ & $<1$ & $<0.3$ & $<0.3$ & $<0.3$ & 1.2 & 0.6 \\
\hline $1,2,3,7,8-\mathrm{PeCDF}$ & 0.75 & 1.4 & $<0.3$ & $<0.3$ & 0.43 & $<0.3$ & $<0.5$ & 0.66 & $<0.1$ & $<0.2$ & 0.65 & 0.35 & $<0.1$ & 0.77 & 0.7 & 0.3 \\
\hline $2,3,4,7,8-\mathrm{PeCDF}$ & 0.8 & 2.1 & $<0.4$ & $<0.6$ & $<0.7$ & $<0.4$ & 0.89 & $<0.4$ & $<0.4$ & $<0.7$ & 2 & $>0.3$ & $<0.3$ & 1.4 & 1.4 & 0.6 \\
\hline $1,2,3,7,8-\mathrm{PeCDD}$ & 0.91 & 1.7 & $<0.4$ & 0.72 & $<2$ & $<0.6$ & $<0.6$ & 1.2 & $<0.9$ & $<1$ & 1.2 & 1 & 0.56 & $<1$ & 1.0 & 0.4 \\
\hline $1,2,3,4,7,8-\mathrm{HxCDF}$ & 2.9 & 2.4 & $<0.3$ & $<0.5$ & 1.1 & $<0.6$ & 1 & 0.84 & $<0.5$ & $<0.6$ & 1.4 & 0.83 & 0.61 & $<2$ & 1.4 & 0.8 \\
\hline $2,3,4,6,7,8-\mathrm{HxCDF}$ & 2.1 & 2.9 & $<0.4$ & 0.82 & 1.9 & 0.82 & 1.3 & 1 & 0.6 & 0.67 & 2.9 & 0.97 & 0.43 & 1.6 & 1.4 & 0.8 \\
\hline $1,2,3,6,7,8-\mathrm{HxCDF}$ & 1.7 & 4.1 & $<0.3$ & 1.5 & 1.6 & 1.5 & 2 & 1.5 & $<1$ & $<1$ & 1.1 & 0.62 & $<0.4$ & 2.2 & 1.8 & 0.9 \\
\hline $1,2,3,7,8,9-\mathrm{HxCDF}$ & $<0.2$ & 1.3 & $<.2$ & $<0.2$ & $<0.3$ & $<0.2$ & $<0.2$ & 0.15 & $<0.4$ & $<0.3$ & $<0.1$ & $<0.08$ & $<0.3$ & $<0.7$ & 0.7 & 0.8 \\
\hline 1,2,3,4,7,8-HxCDD & 1.2 & 2.5 & 0.22 & 0.72 & $<2$ & $<0.7$ & 0.64 & 0.51 & $<0.4$ & 0.5 & 1.1 & 0.63 & $<0.4$ & $<0.7$ & 0.9 & 0.7 \\
\hline 1,2,3,6,7,8-HxCDD & 4 & 7.4 & 1 & 3.3 & 2.3 & 2.1 & 2.6 & 3 & $<2$ & 3.1 & 6.4 & 5 & 3.7 & 3.3 & 3.6 & 1.8 \\
\hline 1,2,3,7,8,9-HxCDD & 1.7 & 5.2 & $<0.5$ & 1.1 & 1.3 & $<2$ & 1.3 & 2.7 & $<0.6$ & $<1$ & 3.5 & 1.8 & 1.3 & $<2$ & 2.2 & 1.4 \\
\hline $1,2,3,4,6,7,8-\mathrm{HpCDF}$ & 42 & 53 & 8.6 & 15 & 27 & 28 & 32 & 32 & 16 & 18 & 24 & 18 & 14 & 48 & 27 & 13 \\
\hline $1,2,3,4,7,8,9-\mathrm{HpCDF}$ & 1.6 & 1.6 & $<0.3$ & 0.46 & 1.2 & 0.76 & 0.99 & 0.97 & $<0.7$ & 0.39 & 1.8 & 1.5 & $<0.2$ & 0.9 & 1.1 & 0.5 \\
\hline $1,2,3,4,6,7,8-\mathrm{HpCDD}$ & 150 & 230 & 30 & 26 & 61 & 59 & 68 & 75 & 50 & 67 & 130 & 150 & 63 & 95 & 90 & 57 \\
\hline OCDF & 400 & 160 & 34 & 23 & 76 & 77 & 68 & 96 & 19 & 36 & 79 & 84 & 22 & 170 & 96 & 99 \\
\hline OCDD & 20900 & 7820 & 540 & 190 & 1290 & 1940 & 690 & 1180 & 420 & 640 & 2560 & 1410 & 500 & 1990 & 3005 & 5495 \\
\hline $\mathrm{WHO}_{98}$ TEQ $\Sigma \mathrm{PCDD} / \mathrm{Fs}$ & 8.6 & 10.2 & 0.8 & 2.0 & 2.0 & 1.7 & 2.5 & 3.5 & 0.8 & 1.4 & 6.8 & 3.9 & 2.0 & 3.2 & 3.5 & 2.9 \\
\hline $\mathrm{WHO}_{05}$ TEQ $\Sigma \mathrm{PCDD} / \mathrm{Fs}$ & 12.7 & 11.3 & 0.9 & 2.0 & 2.3 & 2.1 & 2.5 & 3.8 & 0.9 & 1.5 & 6.9 & 4.2 & 2.1 & 3.4 & 4.0 & 3.7 \\
\hline
\end{tabular}




\begin{tabular}{|c|c|c|c|c|c|c|c|c|c|c|c|c|c|c|c|c|}
\hline PCB 77 & 19 & 37 & 2.9 & 4.7 & 18 & 7.3 & 27 & 13 & 6.1 & 9.2 & 18 & 5 & 3.4 & 24 & 14 & 10 \\
\hline РCB 81 & $<1$ & $<0.6$ & $<0.5$ & 2.3 & 1.8 & $<1$ & 3 & 0.76 & $<0.9$ & $<0.8$ & 1.5 & 0.48 & $<0.2$ & 2.6 & 2 & 1 \\
\hline PCB 126 & 1650 & 2400 & 210 & 110 & 1270 & 280 & 950 & 790 & 560 & 670 & 1210 & 260 & 250 & 1920 & 895 & 712 \\
\hline PCB 169 & 110 & 130 & 12 & 21 & 160 & 29 & 57 & 100 & 45 & 53 & 90 & 28 & 19 & 150 & 72 & 51 \\
\hline PCB 105 & 4480 & 5790 & 540 & 410 & 3250 & 730 & 2840 & 2150 & 1390 & 1640 & 3010 & 700 & 660 & 4850 & 2317 & 1772 \\
\hline PCB 114 & 81 & 120 & 8.6 & 6.3 & 56 & 2 & 42 & 41 & 29 & 32 & 70 & 12 & 8 & 77 & 42 & 35 \\
\hline PCB 118 & 900 & 850 & 88 & 100 & 400 & 130 & 340 & 210 & 98 & 140 & 360 & 84 & 87 & 860 & 332 & 311 \\
\hline PCB 123 & 150 & 240 & 23 & 22 & 90 & 27 & 80 & 52 & 23 & 33 & 85 & 19 & 17 & 200 & 76 & 72 \\
\hline PCB 156 & 280 & 320 & 26 & 30 & 130 & 37 & 120 & 75 & 31 & 51 & 130 & 31 & 28 & 260 & 111 & 103 \\
\hline PCB 157 & 100 & 45 & 5.4 & 8.2 & 29 & 10 & 20 & 14 & 9.6 & 13 & 20 & 6.6 & $<4$ & 49 & 25 & 27 \\
\hline PCB 167 & 8.6 & 10.2 & 0.8 & 2.0 & 2.0 & 1.7 & 2.5 & 3.5 & 0.8 & 1.4 & 6.8 & 3.9 & 2.0 & 3.2 & 3.5 & 2.9 \\
\hline PCB 189 & 12.7 & 11.3 & 0.9 & 2.0 & 2.3 & 2.1 & 2.5 & 3.8 & 0.9 & 1.5 & 6.9 & 4.2 & 2.1 & 3.4 & 4.0 & 3.7 \\
\hline $\mathrm{WHO}_{98}$ TEQ $\Sigma$ PCBs & 3.1 & 5.2 & 0.4 & 0.6 & 2.6 & 0.9 & 3.4 & 1.8 & 0.9 & 1.3 & 2.5 & 0.7 & 0.5 & 3.7 & 2.0 & 1.5 \\
\hline $\mathrm{WHO}_{05}$ TEQ $\Sigma$ PCBs & 2.2 & 4.0 & 0.3 & 0.6 & 2.0 & 0.8 & 3.0 & 1.5 & 0.7 & 1.0 & 2.0 & 0.6 & 0.4 & 2.8 & 1.6 & 1.1 \\
\hline I-TEQ & 27.3 & 16.5 & 1.3 & 1.8 & 3.2 & 3.5 & 3.2 & 4.1 & 1.2 & 2 & 8.6 & 4.8 & 2.2 & 5.2 & 6.1 & 7.3 \\
\hline $\begin{array}{l}\text { WHO }_{98} \text { TEQ } \\
(\Sigma \mathrm{PCDD} \mathrm{Fs}+\Sigma \mathrm{PCBs}) \\
\mathrm{WHO}_{05} \mathrm{TEQ} \\
(\Sigma \mathrm{PCDD} / \mathrm{Fs}+\Sigma \mathrm{PCBs})\end{array}$ & 14.9 & 15.3 & 1.2 & 2.6 & 4.3 & 2.8 & 5.4 & 5.2 & 1.6 & 2.6 & 8.9 & $\begin{array}{l}4.6 \\
4.8 \\
\end{array}$ & 2.5 & 6.1 & $\begin{array}{l}5.5 \\
5.6 \\
\end{array}$ & $\begin{array}{l}4.1 \\
4.5 \\
\end{array}$ \\
\hline Total TCDD & 18 & 29 & 9.7 & 58 & 39.5 & 16 & 41 & 16 & 10 & 10 & 7.9 & 7.8 & 97 & 10 & 26 & 26 \\
\hline Total TCDF & 42 & 70 & 7.7 & 37 & 32 & 9.7 & 87 & 39 & 3.2 & 13 & 110 & 16 & 31 & 5.8 & 36 & 33 \\
\hline Total PeCDD & 19 & 31 & 13 & 26 & 13 & 12 & 21 & 15 & 42 & 81 & 14 & 6.1 & 16 & 140 & 32 & 36 \\
\hline Total PeCDF & 66 & 45 & 4.6 & 34 & 17 & 7 & 43 & 41 & 5.4 & 8 & 260 & 14 & 27 & 7.3 & 41 & 66 \\
\hline
\end{tabular}




\begin{tabular}{|c|c|c|c|c|c|c|c|c|c|c|c|c|c|c|c|c|}
\hline Total HxCDD & 35 & 86 & 9.3 & 23 & 22 & 13 & 28 & 28 & 14 & 23 & 60 & 38 & 37 & 21 & 31 & 20 \\
\hline Total HxCDF & 45 & 46 & 4.6 & 23 & 15 & 29 & 21 & 20 & 8.5 & 11 & 66 & 16 & 24 & 6.2 & 24 & 18 \\
\hline Total HpCDD & 280 & 530 & 56 & 50 & 120 & 130 & 30 & 160 & 87 & 120 & 260 & 270 & 200 & 110 & 172 & 132 \\
\hline Total HpCDF & 78 & 98 & 8.6 & 16 & 41 & 29 & 53 & 56 & 16 & 19 & 69 & 58 & 49 & 14 & 43 & 27 \\
\hline Total PCDD/Fs & 21900 & 8920 & 690 & 480 & 1640 & 2260 & 1180 & 1650 & 630 & 960 & 3490 & 1920 & 2640 & 840 & 3514 & 5709 \\
\hline
\end{tabular}

657

658 
I of dioxin congeners (pg/g d.w.) in sewage sludge from three wastewater treatment plants from Western Australia during $2002,2003,2005$ and 2006.

\begin{tabular}{|c|c|c|c|c|c|c|c|c|c|c|c|c|c|c|c|c|c|c|c|c|c|}
\hline & \multicolumn{8}{|c|}{ Beenyup } & \multicolumn{7}{|c|}{ Subiaco } & \multicolumn{6}{|c|}{ Woodman Point } \\
\hline & \multicolumn{2}{|l|}{2002} & \multicolumn{2}{|l|}{2003} & \multicolumn{2}{|l|}{2005} & \multicolumn{2}{|l|}{2006} & \multicolumn{2}{|l|}{2002} & \multicolumn{2}{|l|}{2003} & \multicolumn{2}{|l|}{2005} & \multirow{2}{*}{$\begin{array}{c}2006 \\
<0.6\end{array}$} & \multicolumn{2}{|l|}{2002} & \multicolumn{2}{|l|}{2003} & \multicolumn{2}{|l|}{2005} \\
\hline & 4.6 & 11.4 & 7.5 & 7.4 & 6 & 5.1 & 2.6 & 2.4 & $<3$ & $<2$ & 4.5 & 3.9 & 4.5 & $<1$ & & $<1.6$ & $<2.0$ & 2.6 & 2.3 & 2.6 & 3 \\
\hline & 0.7 & 1 & 0.26 & 0.32 & $<0.6$ & 0.85 & $<0.8$ & $<1$ & 9.3 & $<0.1$ & 0.48 & 0.63 & 8.3 & $<0.4$ & $<0.3$ & $<0.5$ & $<0.2$ & 0.35 & 0.26 & 0.68 & $<1$ \\
\hline $\mathrm{F}$ & 1.1 & $<6$ & 1.7 & 1.6 & $<0.9$ & $<0.6$ & $<1$ & $<0.7$ & 0.7 & $<0.2$ & 0.5 & 0.56 & 1.2 & $<0.3$ & $<0.1$ & $<0.9$ & 2.1 & 1.1 & 1 & 1.1 & $<0.8$ \\
\hline$) \mathrm{F}$ & 1.7 & 13 & 1.8 & 1.6 & 1.4 & 1.4 & $<0.9$ & $<2$ & $<1$ & $<0.7$ & 0.87 & 0.93 & 1.2 & 0.69 & $<0.3$ & $<0.8$ & 3.2 & 1.1 & 1.2 & 1.4 & 1.4 \\
\hline$) \mathrm{D}$ & 1.2 & 2.8 & 1.5 & 1.5 & 1.2 & $<1$ & $<2$ & $<2$ & $<0.7$ & $<0.4$ & 1.3 & 1.2 & $<0.9$ & $<0.8$ & 0.56 & 0.9 & 2.3 & 1.4 & 1.1 & 2.2 & 1.9 \\
\hline $\mathrm{CDF}$ & 2.8 & 6.8 & 1.5 & $<3$ & 2.2 & 2.6 & $<0.8$ & $<0.8$ & $<3$ & $<3$ & 0.27 & $<0.1$ & 1.6 & 1.3 & 0.61 & 2 & 5.2 & $<2$ & $<1$ & 2.5 & 2.2 \\
\hline $\mathrm{CDF}$ & 2 & 6.7 & 2 & 1.7 & 1.1 & 1.5 & $<0.9$ & $<1$ & 0.8 & $<0.4$ & 0.775 & 0.87 & 0.75 & $<0.5$ & 0.43 & $<0.6$ & 4.4 & 1.8 & 1.8 & 1.5 & 1.6 \\
\hline $\mathrm{CDF}$ & 2.7 & 8 & $<3$ & $<3$ & 2.2 & 2.9 & $<2$ & $<2$ & 1.2 & 1 & $<1$ & $<1$ & 1.5 & 1.3 & $<0.4$ & 1.8 & 6.7 & 2.7 & $<2$ & 2 & 2 \\
\hline $\mathrm{CDF}$ & $<0.4$ & $<3$ & $<0.4$ & $<0.3$ & $<0.4$ & $<0.3$ & $<0.5$ & $<0.8$ & $<0.3$ & $<0.2$ & $<0.4$ & $<0.1$ & $<0.3$ & $<0.2$ & $<0.3$ & $<0.3$ & 0.7 & $<0.3$ & 0.23 & $<0.3$ & $<0.5$ \\
\hline CDD & $<0.5$ & 1.3 & 0.58 & 0.61 & $<0.5$ & $<0.5$ & $<0.8$ & $<0.8$ & $<0.2$ & $<0.1$ & 0.71 & 0.72 & 0.45 & $<0.4$ & $<0.4$ & $<0.3$ & $<2$ & 0.75 & 0.63 & 1.4 & $<0.7$ \\
\hline CDD & 3 & 5.3 & 3.9 & 3.7 & 3.2 & 3.1 & $<2$ & 2.5 & 2.6 & 1.8 & 4.5 & 4.8 & 5 & 5.4 & 3.7 & 3.2 & 13 & 4.2 & 4.3 & 4.6 & 4.3 \\
\hline CDD & $<0.5$ & 1.33 & $<0.9$ & $<0.7$ & $<1$ & 1.5 & $<0.8$ & $<0.7$ & $<1$ & $<0.2$ & $<1$ & $<2$ & $<2$ & $<2$ & 1.3 & 1.8 & $<2$ & $<2$ & $<3$ & 3 & 3.8 \\
\hline $\mathrm{pCDF}$ & 72 & 92 & 110 & 99 & 71 & 72 & 47 & 44 & 30 & 29 & 43 & 43 & 35 & 32 & 14 & 68 & 99 & 99 & 99 & 58 & 54 \\
\hline $\mathrm{pCDF}$ & 1.3 & 1.9 & 1.4 & 1.3 & 1.4 & 1.4 & $<0.6$ & $<2$ & 0.7 & $<0.5$ & $<0.8$ & 0.9 & $<0.6$ & 0.82 & $<0.2$ & 1.5 & 4.3 & 1.6 & 1.4 & 1.5 & 1.6 \\
\hline \multirow[t]{3}{*}{ pCDD } & 87 & 104 & 88 & 85 & 82 & 85 & 62 & 52 & 60 & 65 & 110 & 110 & 150 & 160 & 63 & 83 & 188 & 100 & 100 & 86 & 81 \\
\hline & 333 & 379 & 340 & 330 & 240 & 250 & 170 & 150 & 137 & 137 & 170 & 170 & 60 & 78 & 22 & 321 & 389 & 330 & 320 & 170 & 180 \\
\hline & 882 & 1110 & 860 & 790 & 810 & 830 & 580 & 500 & 592 & 769 & 1270 & 1200 & 1000 & 1210 & 500 & 900 & 1160 & 999 & 990 & 740 & 780 \\
\hline
\end{tabular}




\begin{tabular}{|c|c|c|c|c|c|c|c|c|c|c|c|c|c|c|c|c|c|c|c|c|c|c|}
\hline PCDD/Fs & 6.0 & 16.5 & 6.4 & 6.0 & 5.0 & 4.9 & 1.4 & 1.5 & 10.8 & 1.3 & 5.0 & 5.0 & 12.3 & 3.2 & 2.0 & & 3.4 & 10.1 & 5.7 & 5.1 & 7.0 & 5.8 \\
\hline \multirow[t]{13}{*}{ PCDD/Fs } & 5.9 & 14.2 & 6.3 & 5.9 & 4.9 & 4.8 & 1.6 & 1.6 & 10.9 & 1.5 & 5.1 & 5.1 & 12.2 & 3.3 & 2.1 & & 3.7 & 9.7 & 5.7 & 5.1 & 6.8 & 5.7 \\
\hline & 294 & 373 & 190 & 190 & 180 & 180 & 300 & 190 & 255 & 208 & 98 & 95 & 130 & 110 & 53 & & 481 & 587 & 230 & 230 & 210 & 200 \\
\hline & 14.9 & 40.3 & 8.4 & 8.4 & 7.9 & 8.5 & 13 & 8 & 25.1 & 8.43 & 7.4 & 6.6 & 11 & 5.1 & 2.1 & & 15.9 & 23.4 & 9.9 & 9.5 & 9.4 & 8.3 \\
\hline & 24.2 & 61 & 17 & 16 & 16 & 17 & 12 & 11 & 34.1 & 9.65 & 22 & 13 & 11 & 8.7 & 3.4 & & 26.5 & 31.8 & 18 & 19 & 20 & 19 \\
\hline & $<3$ & $<10$ & 2 & 2.3 & 2.2 & 1.9 & $<1$ & $<1$ & $<2$ & $<2$ & 2.3 & 1.4 & $<1$ & 0.85 & $<0.2$ & & 3.35 & $<5$ & 2.2 & 2.4 & $<2$ & 2.4 \\
\hline & 1970 & 2100 & 860 & 820 & 1000 & 1030 & 680 & 580 & 1240 & 1290 & 810 & 770 & 680 & 680 & 250 & & 1760 & 2250 & 1230 & 1300 & 1700 & 1780 \\
\hline & 130 & 135 & 58 & 70 & 72 & 67 & 49 & 43 & 79 & 87.4 & 67 & 64 & 48 & 42 & 19 & & 148 & 172 & 120 & 100 & 130 & 120 \\
\hline & 3780 & 4710 & 2280 & 2110 & 2330 & 2400 & 1810 & 1490 & 2680 & 2600 & 2200 & 2280 & 1590 & 1410 & 660 & & 3880 & 5040 & 3560 & 3190 & 4190 & 4010 \\
\hline & 91 & 144 & 48 & 45 & 61 & 61 & 29 & 29 & 55.6 & 52.8 & 51 & 60 & 49 & 44 & 8 & & 124 & 84.4 & $<100$ & 73 & 99 & 97 \\
\hline & 629 & 726 & 320 & 300 & 360 & 320 & 220 & 200 & 408 & 387 & 270 & 310 & 220 & 200 & 87 & & 623 & 684 & 440 & 390 & 570 & 560 \\
\hline & 119 & 161 & 100 & 72 & 80 & 89 & 49 & 45 & 80.2 & $<70$ & 7 & 63 & 47 & 45 & 17 & & $<100$ & 161 & 75 & 110 & 140 & 150 \\
\hline & 767 & 797 & 240 & 380 & 150 & 150 & 68 & 68 & 497 & 420 & 360 & 340 & 63 & 100 & 28 & & 719 & 929 & 490 & 540 & 210 & 220 \\
\hline & 35.5 & 31 & 16 & 15 & 19 & 20 & 16 & $<10$ & 19.7 & $<20$ & $<10$ & 14 & 13 & $<10$ & $<4$ & & 33.9 & 38.6 & $<20$ & 24 & 23 & 27 \\
\hline PCBs & 3.5 & 7.4 & 2.3 & 2.2 & 2.2 & 2.3 & 1.6 & 1.5 & 4.1 & 1.6 & 2.7 & 1.9 & 1.5 & 1.2 & 0.5 & 0.0 & 3.7 & 4.5 & 2.6 & 2.7 & 3.0 & 3.0 \\
\hline \multirow[t]{2}{*}{ PCBs } & 2.7 & 6.4 & 1.9 & 1.8 & 1.8 & 1.9 & 1.3 & 1.2 & 3.6 & 1.1 & 2.4 & 1.5 & 1.2 & 1.0 & 0.4 & 0.0 & 3.0 & 3.5 & 2.1 & 2.2 & 2.2 & 2.2 \\
\hline & 6.5 & 16.5 & 6.7 & 6.3 & 5.4 & 5.9 & 2.1 & 2.1 & 11.4 & 2.1 & 5.6 & 5.7 & 13.3 & 4.4 & 2.2 & & 4.1 & 10.3 & 6.2 & 5.7 & 6.7 & 5.7 \\
\hline$\Sigma$ PCBs) & 9.5 & 23.9 & 8.7 & 8.2 & 7.3 & 7.2 & 3.1 & 3.0 & 14.9 & 2.9 & 7.7 & 6.9 & 13.8 & 4.4 & 2.5 & & 7.1 & 14.6 & 8.3 & 7.8 & 10.0 & 8.7 \\
\hline \multirow[t]{3}{*}{$\Sigma$ PCBs) } & 8.6 & 20.6 & 8.2 & 7.7 & 6.8 & 6.7 & 2.9 & 2.8 & 14.5 & 2.6 & 7.5 & 6.6 & 13.4 & 4.3 & 2.5 & & 6.7 & 13.2 & 7.8 & 7.2 & 9.1 & 7.9 \\
\hline & 13 & 66 & 16 & 14 & 9.7 & 8.4 & $<4$ & $<6$ & 18 & 13 & 48 & 50 & 32 & 22 & 5.8 & & 14 & 28 & 19 & 18 & 26 & 20 \\
\hline & 28 & 219 & 41 & 39 & 33 & 32 & 23 & 19 & 19 & 14 & 26 & 23 & 120 & 20 & 10 & & 22 & 19 & 27 & 24 & 21 & 19 \\
\hline
\end{tabular}




\begin{tabular}{|c|c|c|c|c|c|c|c|c|c|c|c|c|c|c|c|c|c|c|c|c|c|}
\hline & 21 & 59 & 23 & 22 & 28 & 11 & 0.7 & 10 & 38 & 9.9 & 45 & 110 & 730 & 7710 & 7.3 & 5.6 & 45 & 19 & 19 & 15 & 28 \\
\hline & 12 & 119 & 31 & 27 & 23 & 18 & 8 & 9.7 & 11 & 10 & 17 & 18 & 30 & 16 & 140 & 10 & 29 & 23 & 22 & 21 & 22 \\
\hline & 23 & 77 & 40 & 36 & 25 & 25 & 20 & 16 & 13 & 9.6 & 31 & 34 & 30 & 32 & 6.2 & 13 & 119 & 35 & 44 & 53 & 1 \\
\hline & 20 & 59 & 38 & 29 & 21 & 23 & 15 & 17 & 10 & 5.1 & 15 & 14 & 11 & 10 & 21 & 14 & 43 & 29 & 28 & 21 & 20 \\
\hline & 159 & 198 & 180 & 170 & 150 & 160 & 110 & 89 & 109 & 119 & 220 & 220 & 240 & 260 & 14 & 154 & 348 & 200 & 200 & 160 & 160 \\
\hline & 117 & 136 & 170 & 150 & 100 & 110 & 66 & 58 & 49 & 48 & 36 & 38 & 49 & 49 & 110 & 111 & 152 & 160 & 150 & 89 & 84 \\
\hline is & 1610 & 2420 & 1740 & 1610 & 1440 & 1470 & 1000 & 870 & \begin{tabular}{|l|l}
996 \\
\end{tabular} & 1130 & 1880 & 1880 & 2300 & 2410 & 840 & 1560 & 2330 & 1840 & 1820 & 1320 & 1350 \\
\hline
\end{tabular}


Table 6

Contamination grading for sewage sludge based on octachloro dibenzo-p-dioxin (OCDD) concentration $\mathrm{ng} \mathrm{kg}^{-1} \mathrm{~d} . \mathrm{w}$. and compared to calculated I-TEQ $\mathrm{ng} \mathrm{kg}^{-1}$ concentration

\begin{tabular}{|c|c|c|}
\hline Grading & OCDD & I-TEQ $^{1}$ \\
\hline Very Low & $150-1,000$ & $1-5$ \\
\hline Low & $1,000-10,000$ & $5-38$ \\
\hline Moderate & $10,000-60,000$ & $38-171$ \\
\hline High & $60,000-200,000$ & $171-475$ \\
\hline Extremely High & $200,000+$ & $475+$ \\
\hline
\end{tabular}

660

661 